\title{
Perbedaan Hasil Belajar antara Pembelajaran Problem Based Learning dengan Eksperimen dan Tanpa Eksperimen Pada Siswa Kelas XI IPA SMA 2 Sendawar
}

\author{
Nurti Yanti ${ }^{1 *}$, M. Khairul Ali Hanif ${ }^{2}$, Abdul Hakim ${ }^{3}$ \\ 1,2,3 Program Studi Pendidikan Fisika, FKIP Universitas Mulawarman \\ Jalan Muara Pahu Samarinda, Indonesia \\ *E-mail: nurtiyor95@gmail.com
}

\begin{abstract}
Abstrak
Tujuan Penelitian ini adalah untuk mengetahui perbedaan hasil belajar siswa antara pembelajaran yang menggunakan problem based learning dengan eksperimen dan tanpa eksperimen pada siswa kelas XI IPA, materi fluida statis dan dinamis. Jenis penelitian ini adalah penelitian kuasi eksperimen. Populasi pada penelitian ini adalah seluruh siswa kelas XI SMA Negeri 2 Sendawar tahun pembelajaran 2018/2019. Teknik pengambilan sampel yang digunakan adalah convenient sampling, sampel yang digunakan adalah siswa kelas XI IPA 2 (sebagai kelas eksperimen) dan siswa XI IPA 3 (sebagai kelas kontrol) dimana masing masing kelas terdapat 35 siswa. Pengumpulan data dalam penelitian ini menggunakan teknik tes tertulis untuk mengetahui hasil belajar siswa pada kelas eksperimen dan kelas kontrol. Setelah diterapkan model pada masing-masing kelas diperoleh hasil belajar pada kelas eksperimen sebesar 75 dan pada kelas kontrol sebesar 61 . Terdapat perbedaan hasi belajar yang signifikan antara pembelajaran problem based learning pada kelas yang menggunakan eksperimen dan yang tanpa eksperimen.
\end{abstract}

Kata kunci : Eksperimen, Problem Based Learning, Hasil Belajar

\section{Abstract}

The purpose of this study was to determine the differences in student learning outcomes between problem based learning learning with experiments and without experiments in class XI IPA students, static and dynamic fluid material. This type of research is quasi experimental study. The population in this study were all students of 11th grade of SMA Negeri 2 Sendawar in the 2018/2019 study year. The sampling technique used was convenient sampling, the sample used was students of class XI IPA 2 (as an experimental class) and students of XI IPA 3 (as a control class) where each class contained 35 students. Data collection in this study uses written test techniques to determine student learning outcomes in the experimental class and the control class. After applying the model in each class the learning outcomes obtained in the experimental class by 75 and in the control class by 61. There are significant differences in learning outcomes between learning problem based learning in classes that use experiments and those without experiments.

Keywords: Learning Outcomes, Problem Based Learning, Experiments

Article History: Received: 13 Desember 2019

Revised : 27 Januari 2020

Accepted: 6 Januari 2020

Published: 31 Januari 2020

How to cite: Yanti, N., Hanif, M.K.A., dan Hakim, A. (2020). Perbedaan Hasil Belajar Antara Pembelajaran Problem Based Learning dengan Eksperimen dan Tanpa Eksperimen Pada Siswa Kelas XI IPA SMA 2 Sendawar, 1(1). pp. 35-44. Retrieved from http://jurnal.fkip.unmul.ac.id/index.php/jpfp/index

Copyright (C) Januari 2020, Jurnal Literasi Pendidikan Fisika

\section{PENDAHULUAN}

Pendidikan merupakan bagian integral dalam pembangunan. Proses pendidikan tak dapat dipisahkan dari proses pembangunan itu sendiri. Pembangunan diarahkan dan bertujuan untuk mengembangkan sumberdaya manusia 
yang berkualitas dan pembanguan ekonomi, yang satu dengan yang lainnya saling berkaitan dan berlangsung secara bersamaan.

Melalui pendidikan dapat diperoleh ilmu pengetahuan yang merupakan bekal kehidupan. Pendidikan dibedakan menjadi dua jenis yaitu pendidikan formal dan pendidikan nonformal. Pendidikan dapat diperoleh melalui belajar. Belajar merupakan hal yang sangat mendasar yang tidak bisa lepas dari kehidupan semua orang.

Ibrahim dan Nur (Rusman, 2010) mengemukakan bahwa pembelajaran berbasis masalah merupakan salah satu pendekatan pembelajaran yang digunakan untuk merangsang berpikir tingkat tinggi siswa dalam situasi yang berorientasi pada masalah dunia nyata, termasuk di dalamnya belajar bagaimana belajar.

Ciri utama pembelajaran berbasis masalah adalah adanya pengajuan pertanyaan atau masalah, memusatkan keterkaitan antardisiplin, penyelidikan autentik, kerja sama, serta menghasilkan karya dan peragaan (Suyanto dan Jihad, 2013).

Problem based learning (PBL) merupakan model pembelajaran yang sangat populer dalam dunia kedokteran sejak tahun 1970-an. PBL berfokus pada penyajian suatu permasalahan (nyata atau simulasi) kepada siswa, kemudian siswa diminta mencari pemecahannya melalui serangkaian penelitian dan investigasi berdasarkan teori, konsep, prinsip yang dipelajarinya dari berbagai bidang ilmu (multiple perspective). Permasalahan menjadi fokus, stimulus, dan pemandu proses belajar. Sementara, guru menjadi fasilitator dan pembimbing (Siregar dan Nara, 2010).

Belajar merupakan sebuah proses yang kompleks yang terjadi pada semua orang dan berlangsung seumur hidup, sejak masih bayi (bahkan dalam kandungan) ingga liang lahat. Salah satu pertanda bahwa seseorang telah belajar sesuatu adalah adanya perubahan tingkah laku tersebut menyangkut perubahan yang bersifat pengetahuan (kognitif) dan keterampilan (psikomotor) maupun yang menyangkut nilai dan sikap (afektif) (Nara, 2010).

Tujuan belajar adalah sejumlah hasil belajar yang menunjukkan bahwa siswa telah melakukan perbuatan belajar, yang umumnya meliputi pengetahuan, keterampilan dan sikapsikap yang baru, yang diharapkan dapat dicapai oleh siswa menurut Jihad dan Abdul (2008).

Belajar merupakan proses dalam diri individu yang berinteraksi dengan lingkungan untuk mendapatkan perubahan dalam perilakunya. Belajar adalah aktivitas mental psikis yang berlangsung dalam interaksi aktif dengan lingkungan yang menghasilkan perubahanperubahan dalam pengetahuan, keterampilan dan sikap. Perubahan itu diperoleh melalui usaha (bukan karena kematangan), menetap dalam waktu yang relative dan merupakan hasil pengalaman (Purwanto,2014).

Dalam dunia pendidikan, khususnya dunia persekolahan pengukuran hasil belajar sangatlah diperlukan, guna untuk mengetahui tingkat keberhasilan siswa dalam belajar. Untuk mengetahui hasil belajar siswa dilakukan dengan cara memberikan penilaian atau evaluasi dengan tujuan supaya siswa mengalami perubahan yang positif. Evaluasi adalah usaha untuk memperoleh informasi berupa umpan balik (feed-back) bagi penyempurnaan pendidikan (Sugiyono,2010).

Dalam proses belajar mengajar dengan eksperimen ini siswa diberi kesempatan untuk mengalami sendiri atau melakukan sendiri, mengikuti proses, mengamati suatu objek, menganalisis, membuktikan, dan menarik kesimpulan tentang suatu objek keadaan atau suatu proses (Sagala, 2012).

Metode eksperimen adalah cara penyajian pelajaran dimana siswa melakukan percobaan dengan mengalami dan membuktikan sendiri sesuai yang dipelajari (Djamarah, 2010).

Sumberdaya manusia yang mumpuni tentunya dapat tercipta dari pendidikan yang diterima oleh manusia tersebut. Dalam hal ini tentunya peran guru sebagai pendidik sangatlah vital. Guru tidak hanya dituntut untuk dapat memberikan materi dengan baik tetapi juga mendidik siswanya agar memiliki ahlak yang baik pula sehingga kelak ketika siswa telah menyelesaikan pendidikannya maka siswa tersebut dapat terjun kemasyarakat dengan baik. Dalam menyampaikan pembelajaran guru tentunya memiliki solusi masing-masing untuk menyelesaikan permasalahan yang ada disekolah tempat guru tersebut mengajar.

Pembelajaran fisika hanya bergantung pada buku teks dengan metode menghapal daripada 
memahami konsep, padahal seharusnya pembelajaran fisika untuk menumbuhkan kemampuan berpikir, bekerja dan bersikap ilmiah serta mengkomunikasikannya. Selain itu, masalah lainnya adalah siswa cendrung menjadi pembelajar yang pasif karena hanya mendengarkan penjelasan dari guru dan menyalin informasi yang diterimanya dari guru kemudian siswa mengerjakan soal-soal yang diberikan guru, sehingga membuat siswa bosan mengikuti pembelajaran fisika.

Pembelajaran fisika mempunyai peran besar dalam menciptakan sumberdaya manusia yang berkualitas. Sehingga dunia pendidikan di Indonesia, diharapkan dapat melahirkan lulusan yang cakap dalam fisika dan dapat menumbuhkan kemampuan berfikir logis, kritis, kreatif, inisiatif, dan bersifat adaptif terhadap perubahan.

Pelajaran fisika sebagai salah satu rumpun ilmu IPA, pada hakikatnya juga terdiri dari aspek produk dan proses. Sebagai sebuah produk, fisika merupakan sekumpulan pengetahuan tentang fakta, konsep, generalisasi, prinsip, teori, dan hukum fisika. Sementara sebagai suatu proses, fisika merupakan serangkaian proses ilmiah yang dilakukan dalam menemukan pengetahuan-pengetahuan tentang fisika. Maka, pemahaman terhadap fisika seharusnya tidak hanya memandang fisika sebagai produk tetapi juga sebagai proses. Dalam proses pembelajaran fisika, kegiatan pembelajaran tidak hanya ditekankan pada produk saja, tetapi juga harus diimbangi dengan aspek proses. Hal ini sejalan dengan tuntutan kurikulum 2013 yang menginginkan agar dalam proses pembelajaran harus terdapat aspek sikap, pengetahuan dan keterampilan.

Berdasarkan hasil wawancara yang dilakukan disekolah Pembelajaran fisika yang disampaikan dikelas masih sebatas pada metode ceramah yang membuat siswa tidak aktif dan pasif. Siswa hanya mendengarkan dan mencatat hal-hal yang disampaikan guru. Sehingga siswa menjadi cepat bosan. Hal tersebut disebabkan karena keterbatasan guru dalam pembelajaran fisika. Untuk itu, perlu menerapkan pembelajaran eksperimen pada problem based learning

Sedangkan dunia pendidikan sekarang ini mayoritas pendidik masih menggunakan metode ceramah dalam pembelajaran. Metode ini sering kali digunakan karena metode ini dianggap mampu dilakukan pada materi apapun dan lebih praktis karena hanya berpusat pada guru. Karena metode ini sering dilakukan sehingga siswa merasa jenuh dan bosan. Perasaan yang jenuh dan bosan tentunya akan berimbas pada kurangnya materi yang diserap oleh siswa selama pembelajaran. Dengan berkembangnya teknologi dewasa ini maka banyak solusi yang dapat kita temukan untuk mengatasi suasana yang kurang menarik didalam kelas sehingga dapat menciptakan suasana kelas yang lebih aktif dan kondusif.

Berdasarkan hasil observasi yang dilakukan di SMA Negeri 2 Sendawar pada tanggal 16 Agustus 2018, Permasalahan ang terjadi selama pembelajaran fisika adalah hasil belajar yang didapat oleh siswa masih kurang maksimal karena pelajaran fisika yang dianggap susah dan rumit oleh siswa. pembelajaran yang digunakan masih monoton karena hanya menggunakan metode ceramah pada pelajaran fisika membuat siswa tidak aktif didalam kelas ditambah dengan pelajaran fisika yang dianggap sulit oleh siswa membuat pembelajaran dikelas menjadi tidak maksimal karena hanya guru yang berperan aktif didalam kelas dan bukan siswanya.

Berdasarkan permasalahan diatas, maka dibutuhkan metode yang membuat siswa menjadi tertarik dalam belajar untuk mengamati pelajaran yang akan diberikan oleh guru sehingga akan membuat siswa aktif dan kelas akan menjadi aktif dan kondusif. Oleh sebab itu peneliti akan menggunakaneksperimen pada pembelajaran problem based learning. Eksperimen adalah cara penyajian pembelajaran dimana siswa melakukan percobaan dengan mengalami secara langsung untuk membuktikan sendiri suatu pertanyaan atau hipotesis yang dipelajari. Dengan menggunakan media ini siswa akan dituntut untuk menjadi lebih aktif karena dengan menggunakan eksperimen maka siswa akan dituntut untuk berperan langsung dalam pembelajaran tersebut.

Metode eksperimen pada pembelajaran problem based learning ini diharapkan dapat memberikan ada atau tidak perbedaan hasil belajar dengan pembelajaran yang menggunakan eksperimen dan tanpa 
eksperimen pada siswa kelas XI IPA SMA Negeri 2 Sendawar.

Rumusan masalah untuk mengetahui perbedaan hasil belajar antara pembelajaran problem based learning dengan eksperimen dan tanpa eksperimen pada siswa kelas XI IPA SMA Negeri 2 Sendawar. Penelitian ini bertujuan untuk mengetahui ada atau tidak perbedaan hasil belajar antara pembelajaran problem based learning dengan eksperimen dan tanpa eksperimen pada siswa kelas XI IPA SMA Negeri 2 Sendawar pada materi fluida statis.

\section{METODE}

Populasi pada penelitian ini adalah siswa kelas XI IPA SMA Negeri 2 Sendawar tahun ajaran 2018/2019 beralamat di Barong Tongkok kab. Kutai Barat.

Teknik pengambilan sampel dalam penelitian adalah seluruh siswa kelas XI IPA SMA Negeri 2 Sendawar. Teknik pengambilan sampel dalam penelitian ini adalah dua kelas yang diambil secara convenient sampling, sampel diambil dari XI IPA 3 (35 orang) sebagai kelas eksperimen dan kelas XI IPA 2 ( 35 orang) sebagai kelas kontrol.

Penelitian komparatif yaitu penelitian yang bersifat membandingkan persamaan dan perbedaan dua atau lebih fakta-fakta dan sifatsifat objek yang diteliti.

Memenuhi data yang diperlukan dalam penelitian, instrumen yang digunakan adalah instrumen tes. Instrumen tes yang digunakan merupakan tes uraian. Pemberian tes dilakukan di pertemuan awal pembelajaran (pretest) dan pertemuan terakhir dari pembelajaran (posttest).

Mengetahui Perbedaan Hasil Belajar antara Pembelajaran Problem Based Learning dengan Eksperimen dan Tanpa Ekspeirmen menggunakan Uji normalitas ini dilakukan untuk mengetahui apakah sampel pretest dan posttest kelas eksperimen dan kelas kontrol yang diteliti berdistribusi normal atau tidak. Uji kenormalan yang dilakukan adalah uji One Kolmogorof Smirnov dengan taraf signifikan $5 \%$, Setelah uji normalitas, kemudian dilakukan uji homogenitas untuk pretest dan posttest kelas eksperimen dan kelas kontrol untuk mengetaui kesamaan antara dua keadaan atau populasi, dan pengujian homogenitas adalah pengujian mengenai sama tidaknya variansi variansi dua buah distribusi atau lebih. Untuk menguji homogenitas pada penelitian ini menggunakan uji homogeneity of variences dengan taraf signifikan 5\%. uji t tidak berpasangan. Untuk mengetahui pengaruh model pembelajaran yang diterapkan pada kelas kontrol dan kelas eksperimen terhadap hasil belajar siswa digunakan uji $t$ tidak berpasangan (independent samples $t$-test) dengan menggunakan aplikasi SPSS, jika uji prasyarat sudah terpenuhi dan data dinyatakan berdistribusi normal serta kedua kelompok sampel mempunyai varian yang sama, maka dapat dilakukan uji $t$ test variabel bebas/ Independent Sampels t-test. Kriteria pengujian uji $t$-test adalah jika angka signifikansi yang dihasilkan lebih kecil dari 0,05

Data untuk mengetahui presentase hasil belajar siswa, digunakan rumus :

$$
\mathrm{P}=\frac{F}{N} \times 100 \%
$$

\section{HASIL DAN PEMBAHASAN}

\section{HASIL}

Data hasil penelitian meliputi data hasil belajar siswa-siswi kelas XI IPA 2 dan IPA 3 pada materi Fluida Statis dan Dinamis yang diukur menggunakan instrumen penilaian tes uraian. Data yang telah didapatkan akan diolah dengan uji $t$ tidak berpasangan. Untuk mengetahui apakah ada perbedaan hasil belajar antara pembelajaran problem based learning dengan eksperimen dan tanpa eksperimen digunakan uji t tidak berpasangan.

Pembelajaran fisika pada kelas XI IPA 2 menggunkan model pembelajaran problem based learning dengan eksperimen dan dikelas XI IPA 3 menggunkan pembelajaran yang sama tetapi tanpa eksperimen. sebelum dilakukan pembelajaran terlebih dahulu diberikan pretest pada kelas eksperimen dan kelas kontrol untuk mengetahui kemampuan awal siswa pada kedua kelas tersebut.

Pembelajaran fisika dikelas XI IPA 2 siswa diajarkan dengan menggunakan pembelajaran problem based learning dengan eksperimen tentang materi fluida statis dan dinamis. Pada proses pembelajaran ini siswa dibagi menjadi 5 kelompok untuk menyelesaikan lembar kerja peserta didik (LKPD) yang telah dibagikan. 
Respon siswa terhadap proses pembelajaran sangat aktif meskipun ada beberapa siswa yang kurang aktif berdiskusi dalam kelompok, namun ada beberapa siswa yang aktif dan menonjol dalam kelompoknya.

Penilaian pretest siswa pada penelitian ini menggunakan 2 sampel kelas dari kelas XI IPA 2 sebagai kelas eksperimen dan kelas XI IPA 3 sebagai kelas kontrol Uji pemahaman. Dilakukan dengan menggunakan soal tes yang terdiri dari 10 soal. Berdasarkan hasil penilaian belajar siswa nilai pretest pada kelas eksperimen dan kontrol sebelum dilakukan perlakuan yang berbeda pada kelas eksperimen dan kelas kontrol. Pada kelas eksperimen siswa memperoleh nilai dengan rata-rata 43,28 sedangkan pada kelas kontrol siswa memperoleh nilai rata-rata 36,00. Dengan jumlah total sampel siswa pada kelas eksperimen 35 dan pada kelas kontrol 35 siswa. Pada hasil pretes nilai tertinggi pada kelas eksperimen dengan nilai terendah 30 dan nilai tertinggi 55 , sedangakan pada kelas kontrol nilai terendah 30 dan nilai tertinggi 50 dari total skor maksimum 100. Standar deviasi yang diperoleh pada hasil pretest pada kelas eksperimen adalah 8,39 sedangkan pada kelas kontrol 6,83. Dari kedua hasil pretest tersebut tingkat hasil belajar siswa kelas eksperimen dan kontrol masih kurang terlihat dari hasil nilai rata-rata siswa.

Penilaian posttest siswa hasil data yang diperoleh dari posttest yang dilakukan pada kelas eksperimen dan kelas kontrol menunjukkan bahwa nilai tertinggi pada kelas eksperimen sebesar 95 dan nilai terendah 50 dengan nilai rata-rata sebesar 75,42, sedangkan pada kelas kontrol nilai tertinggi sebesar 85 dan nilai terendah sebesar 30 dengan nilai rata-rata sebesar 61,14 .

Pegujian statistik dari hasil pretest dan posttest hasil belajar siswa pada kelas eksperimen dan kelas kontrol menunjukkan bahwa data yang diperoleh tidak terdistribusi normal namun homogen. Uji normalitas yang digunakan adalah uji Shapiro Wilk, pada hasil pretest pada kelas eksperimen dan kontrol menunjukkan bahwa data nilai pre-test pada kelas eksperimen memiliki angka signifikan 0,006 sedangkan pretest pada kelas kontrol memiliki nilai signifikan 0,000 . Dimana data yang dieperoleh harus lebih besar dari 0,05.
Dari data tersebut menunjukkan bahwa kelas eksperimen terdistribusi normal sedangkan kelas kontrol tidak terdistribusi normal karena memiliki nilai kurang dari 0,05 . untuk menguji kelas kontrol sehingga nilai dapat terdistribusi normal menggunakan uji Mann Whitney Non Parametric untuk mengetahui perbedaan pretest kelas eksperimen dan kelas kontrol. Hasil uji mann whitney non parametrik tersebut diperoleh data nilai lebih kecil dari 0,05, maka dapat disimpulkan $\mathrm{Ho}_{\mathrm{o}}$ ditolak dan $\mathrm{H}_{\mathrm{a}}$ diterima sehingga terdapat perbedaan signifikan antara kelas eksperimen dan kelas kontrol .

Uji normalitas data dilakukan untuk menguji apakah semua data berdistribusi normal atau tidak. Untuk mengetahui kriteria pengujian data memiliki sebaran distribusi normal jika angka signifikansi yang dihasilkan lebih besar dari 0,05 (sig < 0,05). Hasil data yang diperoleh menunjukkan bahwa data nilai pre-test pada kelas eksperimen memiliki angka signifikan 0,006 sedangkan pretest pada kelas kontrol memiliki nilai signifikan 0,000 . Dimana data yang dieperoleh harus lebih besar dari 0,05. Dari data tersebut menunjukkan bahwa kelas eksperimen terdistribusi normal sedangkan kelas kontrol tidak terdistribusi normal karena memiliki nilai kurang dari 0,05 . untuk menguji kelas kontrol sehingga nilai dapat terdistribusi normal menggunakan uji Mann Whitney Non Parametric untuk mengetahui perbedaan pretest kelas eksperimen dan kelas kontrol. Hasil uji mann whitney non parametrik tersebut diperoleh data nilai lebih kecil dari 0,05, maka dapat disimpulkan $\mathrm{Ho}_{\mathrm{o}}$ ditolak dan $\mathrm{H}_{\mathrm{a}}$ diterima sehingga terdapat perbedaan signifikan antara kelas eksperimen dan kelas kontrol .

Untuk pengujian homogenitas varian masing-masing skor post-test kedua kelompok baik eksperimen maupun kontrol akan dibandingkan. Uji homogenitas data menggunakan taraf signifikan 0,05. Data dikatakan homogen jika nilai signifikansi lebih besar dari 0,05. Berdasarkan data yang diperoleh menunjukkan hasil uji homogenitas dengan tarraf signifikansi sebesar 0,993 sehingga lebih besar dari 0,05, maka dapat disimpulkan bahwa skor post-tes kelass eksperimen dan kelas kontrol adalah homogen.

Dalam uji normlitas dan uji homogenitas menunjukkan bahwa data termasuk dalam data distribusi normal dan memiliki varian yang 
Perbedaan Hasil Belajar

sama, sehingga data tersebut memenuhi syarat untuk dilakukan uji t. Analisis uji $\mathrm{t}$ dua variabel tidak berhubungan atau independent samples ttest untuk mengetahui apakah ada perbedaan hasil belajar siswa pada pembelajaran problem based learning pada siswa kelas eksperimen dan kelas kontrol. Analisis ini dilakukan dengan tujuan untuk mengetahui ada atau tidaknya perbedaan rata-rata antara dua kelompok kelas yang tidak berhubungan atau tidak mempunyai keterlibatan satu sama lain. Hasil data yang diperoleh menunjukkan perbandingan nilai ratarata, simpangan baku dan jumlah sampel pada masing-masing kelompok data yang dibandingkan. Hasil output menunjukkan bahwa nilai thitung $=4,74$ dengan angka signifikansi sebesar 0,000 (2-tailed). Nilai signifikansi tersebut $<0,05$ sehingga kedua data memiliki perbedaan yang signifikan antara nilai post-test kelas eksperimen XI IPA 2 dan kelas kontrol XI IPA 3.

Tabel 1. Rata-rata hasil pretest dan posttest kelas eksperimen

\begin{tabular}{lccccc}
\hline & \multicolumn{4}{c}{ Descriptive Statistics } \\
\hline & N & Min & Maks & Mean & Std. Deviasi \\
\hline $\begin{array}{l}\text { Hasil pretest } \\
\begin{array}{l}\text { kelas } \\
\text { eksperimen }\end{array}\end{array}$ & 35 & 30,00 & 55,00 & 43,2857 & 8,39668 \\
\hline $\begin{array}{l}\text { Hasil posttest } \\
\begin{array}{l}\text { Kelas } \\
\text { Eksperimen }\end{array}\end{array}$ & 35 & 50,00 & 95,00 & 75,4286 & 12,20965 \\
\hline
\end{tabular}

Tabel 2. Rata-rata hasil pretest dan posttest kelas kontrol

\begin{tabular}{lccccc}
\hline \multicolumn{5}{c}{ Descriptive Statistics } \\
\hline & N & Min & Maks & Mean & Std. Deviasi \\
\hline $\begin{array}{l}\text { Hasil pretest } \\
\text { kelas } \\
\text { eksperimen }\end{array}$ & 35 & 30,00 & 50,00 & 36,0000 & 6,83847 \\
\hline $\begin{array}{l}\text { Hasil posttest } \\
\begin{array}{l}\text { Kelas } \\
\text { Eksperimen }\end{array}\end{array}$ & 35 & 30,00 & 85,00 & 61,1429 & 13,00937 \\
\hline
\end{tabular}

Berdasarkan hasil penilaian belajar siswa nilai pretest pada kelas eksperimen dan kontrol sebelum dilakukan perlakuan yang berbeda pada kelas eksperimen dan kelas kontrol. Pada kelas eksperimen siswa memperoleh nilai dengan rata-rata 43,28 sedangkan pada kelas kontrol siswa memperoleh nilai rata-rata 36,00. Dengan jumlah total sampel siswa pada kelas eksperimen 35 dan pada kelas kontrol 35 siswa. Pada hasil pretes nilai tertinggi pada kelas eksperimen dengan nilai terendah 30 dan nilai tertinggi 55, sedangakan pada kelas kontrol nilai terendah 30 dan nilai tertinggi 50 dari total skors maksimum 100. Standar deviasi yang diperoleh pada hasil pretest pada kelas eksperimen adalah 8,39 sedangkan pada kelas kontrol 6,83. Dari kedua hasil pretest tersebut tingkat hasil belajar siswa kelas eksperimen dan kontrol masih kurang terlihat dari hasil nilai rata-rata siswa.

Hasil data yang diperoleh dari posttes yang dilakukan pada kelas eksperimen dan kelas kontrol menunjukkan bahwa nilai tertinggi pada kelas eksperimen sebesar 95 dan nilai terendah 50 dengan nilai rata-rata sebesar 75,42, sedangkan pada kelas kontrol nilai tertinggi sebesar 85 dan nilai terendah sebesar 30 dengan nilai rata-rata sebesar 61,14 . Hasil ratarata pretest-posttest pada table 1 dan 2 .

Tabel 3. Persentase Ketuntasan Hasil Belajar Pretest dan Posttest Kelas Eksperimen

\begin{tabular}{lccccc}
\hline $\begin{array}{l}\text { Interval } \\
\text { Nilai }\end{array}$ & Pretest & Posttest & Keterangan & Persentase \\
\hline & & & & Pretest Posttest \\
\hline $75 \geq X>100$ & 0 & 23 & Tuntas & $0 \%$ & $65,71 \%$ \\
\hline $0 \geq X>75$ & 35 & 12 & Tidak Tuntas & $100 \%$ & $34,29 \%$
\end{tabular}

Tabel 4. Persentase Ketuntasan Hasil Belajar Pretest dan Posttest Kelas Kontrol

\begin{tabular}{lccccc}
\hline $\begin{array}{l}\text { Interval } \\
\text { Nilai }\end{array}$ & Pretest & Posttest & Keterangan & \multicolumn{2}{c}{ Persentase } \\
\hline $75 \geq X>100$ & 0 & 5 & Tuntas & $0 \%$ & $14,29 \%$ \\
\hline $0 \geq X>75$ & 35 & 30 & Tidak Tuntas & $100 \%$ & $85,71 \%$ \\
\hline
\end{tabular}

Tabel 5. Hasil data frekuensi kelas eksperimen

\begin{tabular}{ccccc}
\hline No & Nilai & $\begin{array}{c}\text { Kelas } \\
\text { Eksperimen }\end{array}$ & Kriteria & Persentase \\
\hline 1. & $80 \leq X \leq 100$ & 16 & Baik sekali & $45,71 \%$ \\
\hline 2. & $70 \leq X<80$ & 9 & Baik & $25,71 \%$ \\
\hline 3. & $60 \leq X<70$ & 8 & Cukup & $22,89 \%$ \\
\hline 4. & $50 \leq X<60$ & 2 & Kurang & $5,71 \%$ \\
\hline 5. & $0 \leq X<50$ & 0 & Kurang sekali & $0 \%$ \\
\hline
\end{tabular}

\begin{tabular}{|c|c|c|c|c|}
\hline No & Nilai & $\begin{array}{r}\text { Kelas } \\
\text { Kontrol }\end{array}$ & Kriteria & Persentase \\
\hline 1. & $80 \leq X \leq 100$ & 4 & Baik sekali & $11,43 \%$ \\
\hline 2. & $70 \leq X<80$ & 7 & Baik & $20 \%$ \\
\hline 3 & $60 \leq X<70$ & 12 & Cukup & $34,29 \%$ \\
\hline 4. & $50 \leq X<60$ & 6 & Kurang & $17,14 \%$ \\
\hline 5. & $0 \leq X<50$ & 5 & Kurang sekali & $14,29 \%$ \\
\hline
\end{tabular}

Tabel 7. Nilai Hasil Belajar Siswa Kelas Eksperimen dan Kelas Kontrol

\begin{tabular}{lcccc}
\hline & \multicolumn{2}{c}{ Kelas Eksperimen } & \multicolumn{2}{c}{ Kelas Kontrol } \\
& Pretest & Posttest & Pretest & Posttest \\
\hline Skor Maksimum & 55 & 95 & 50 & 85 \\
\hline Skor Minimum & 50 & 30 & 30 & 30
\end{tabular}




\begin{tabular}{lcccc}
\hline Rata-rata & 43,29 & 75,43 & 36 & 61,14 \\
\hline $\mathrm{N}$ & 35 & 35 & 35 & 35 \\
\hline
\end{tabular}

\section{PEMBAHASAN}

Hasil rata-rata pretest dan posttest kelas eksperimen menunjukkan bahwa nilai tertinggi pada kelas eksperimen sebesar 95 dan nilai terendah 50 dengan nilai rata-rata sebesar $75,42 \%$. Dari hasil persentase nilai ketuntasan Pretest dan posttest kelas eksperimen menunjukkan 35 siswa tidak tuntas. Pada hasil pretest dan pada hasil posttest 23 siswa tuntas mencapai KKM 75 dan 47 siswa belum mencapai KKM 75. Hasil analisis menunjukkan persentase ketuntasan pada pretest sebesar $0 \%$ dan persentase tidak tuntas sebesar $100 \%$, sedangkan nilai ketuntasan posttest sebesar $65,71 \%$ dan $34,29 \%$ siswa masih belum mencapai ketuntasan.

Hasil rata-rata pretest dan posttest kelas kontrol menunjukkan bahwa nilai tertinggi pada kelas kontrol sebesar 85 dan nilai terendah 30 dengan nilai rata-rata sebesar $61,14 \%$. Dari hasil persentase nilai ketuntasan Pretest dan posttest kelas kontrol menunjukkan 35 siswa tidak tuntas. Pada hasil pretest dan pada hasil posttest 5 siswa tuntas mencapai KKM 75 dan 65 siswa belum mencapai KKM 75. Hasil analisis menunjukkan persentase ketuntasan pada pretest sebesar $0 \%$ dan persentase tidak tuntas sebesar $100 \%$, sedangkan nilai ketuntasan posttest sebesar $14,29 \%$ dan $85,71 \%$ siswa masih belum mencapai ketuntasan.

Penelitian ini bertujuan untuk mengetahui apakah ada perbedaan antara pembelajaran problem based learning dengan eksperimen dan tanpa eksperimen pada siswa kelas XI IPA. Pada materi Fluida Statis dan Dinamis di SMA Negeri 2 Sendawar Tahun ajaran 2018/2019.

Pada penelitian ini digunakan dua kelas XI IPA yaitu XI IPA 2 sebagai kelas eksperimen dan XI IPA 3 sebagai kelas kontrol. Jumlah sampel pada penelitian ini adalah 70 siswa. Tujuan dipilinnya dua kelas adalah agar dapat dibandingkan hasil belajar siswa antara kelas eksperimen yang diberikan perlakuan berupa penggunaan pembelajaran problem based learning dengan kelas kontrol yang hanya menggunakan model pembelajaran yang sama tetapi tidak menggunakan eksperimen.

Penelitian dilakukan sebanyak 6 kali pertemuan untuk kelas XI IPA dengan masingmasing pertemuan pada kelas eksperimen dan kelas kontrol 4 kali pertemuan, dimana kelas eksperimen menggunakan pembelajaran problem based learning sedangkan pada kelas kontrol menggunakan pembelajaran yang sama dengan metode ceramah dan pada pertemuan terakhir dilakukan posttest pada kelas eksperimen dan kelas kontrol,untuk mengukur kemampuan hasil belajar siswa dengan perlakuan pembelajaran yang sama tetapi menggunakan metode eksperimen dan tanpa eksperimen.

Setiap pertemuan yang dilakukan memiliki alokasi waktu selama 8 jam pelajaran $(8 \times 45$ menit) dengan jadwal 2 kali tatap muka dalam seminggu. Jadi jumlah waktu pembelajaran yang diberikan terhadap siswa kelas XI IPA. Pembelajaran dilakukan sebanyak 4 kali pertemuan dengan total 10 jam pembelajaran $(10 \times 45$ menit). Pretest dan posttest dilaksanakan pada kelas eksperimen dan kelas kontrol masing-masing 2 jam pembelajaran, sedangkan total waktu pembelajaran pada kelas eksperimen dan kelas kontrol ada 8 jam pembelajaran.

Instrumen tes yang digunakan untuk mengetahui hasil belajar siswa merupakan tes tertulis dengan 10 soal uraian. Soal uraian untuk mengetahu kemampuan hasil belajar siswa pada kelas eksperimen dan kelas kontrol dengan perlakuan pembelajaran yang sama tetapi menggunakan metode yang berbeda.

Sebelum melaksanakan pembelajaran dengan materi Fluida Statis dan Dinamis, terlebih dahulu diberikan pretest pada pertemuan pertama dikedua kelas. Hal ini dilakukan untuk mengetahui kemampuan masing-masing kelas terhadap penguasaan materi fluida statis dan dinamis. Dari hasil jawaban kedua kelas tersebut, penulis mendapatkan data awal nilai hasil belajar siswa yang terlampir pada lampiran 11 dan lampiran 12. Setelah dilakukan pretest kepada kedua kelas tersebut, selanjutnya siswa diberikan perlakuan berupa pembelajaran fisika dengan pembelajaran problem based learning dengan metode ceramah pada kelas kontrol sedangkan kelas eksperimen diberikan perlakuan berupa 
Perbedaan Hasil Belajar

pembelajaran problem based learning dengan metode eksperimen.

Berdasarkan hasil analisis perhitungan data yang telah diperoleh dapat dilihat pada penilaian hasil pretest bahwa pada kelas kontrol dan kelas eksperimen didapat nilai terendah sebesar 30 dan nilai tertinggi sebesar 55 dengan rata-rata nilai pada kelas eksperimen sebesar 43,29 sedangakan nilai rata-rata pada kelas kontrol sebesar 36,00. Dan setelah hasil pretest di uji homogenitas kemudian didapat hasil signifikansi sebesar 0,248 yang menandakan bahwa hasil signifikansi lebih besar dari taraf signifikansi sebesar 0,05. Hal tersebut dapat dikatakan bahwa kedua kelas termasuk kelas yang homogen.

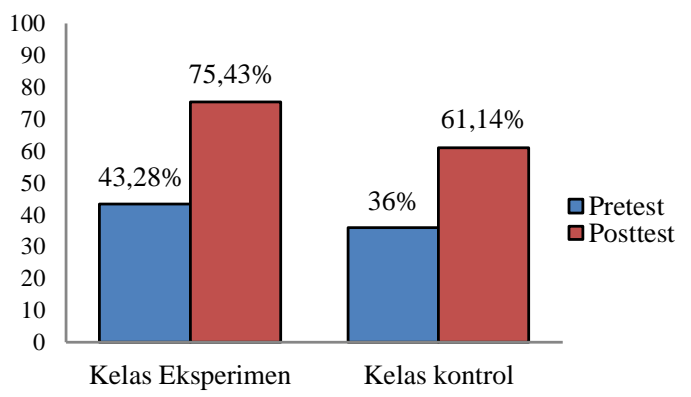

Gambar 1. Grafik Hasil Pretest dan Posttest Kelas Eksperimen dan Kelas Kontrol

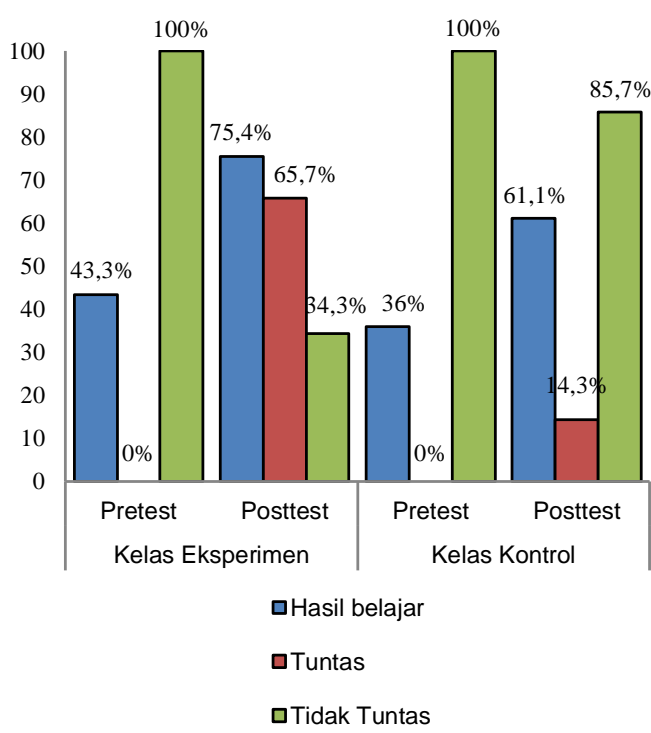

Gambar 2.Grafik Persentase Ketuntasan Hasil Belajar Siswa kelas Eksperimen dan kelas Kontrol

Berdasarkan analisis data yang sudah dilakukan dapat dilihat pada tabel 4 dan tabel 5 , namun peningkatan pada kelas eksperimen lebih baik daripada peningkatan pada kelas kontrol. Pada kelas eksperimen terdapat 16 siswa memperoleh nilai baik sekali dengan persentase $45,71 \%$, 9 siswa kriteria baik dengan persentase $25,71 \%, 8$ siswa kriteria cukup dengan persentase $22,89 \%, 2$ siswa kriteria kurang dengan persentase $5,71 \%$ dan pada kelas kontrol, diperoleh sebanyak 4 peserta didik memperoleh kriteria baik sekali dengan presentase $11,43 \%$, sebanyak 7 peserta didik yang memperoleh kriteria baik dengan presentase $20 \%$, sebanyak 12 peserta didik memperoleh kriteria cukup dengan persentase $34,29 \%$, sebanyak 6 peserta didik memperoleh kriteria kurang dengan persentase $17,14 \%$, dan sebanyak 5 peserta didik dari kelas kontrol memperoleh kriteria kurang sekali dengan persentase $14,29 \%$. Dari data yang diperoleh hasil belajar dari kelas eskperimen dan kelas kontrol terdapat 8 siswa yang memperoleh kriteria niali kurang dan 5 siswa memperoleh nilai kurang sekali dari kelas eksperimen. Dari data tersebut dapat dibuktikan bahwa pada kelas eksperimen mengalami peningkatan daripada kelas kontrol. Hal ini dikarenakan penggunaan pembelajaran problem based learning pada kelas eksperimen melibatkan secara langsung kemampuan peserta didik untuk mencari dan menemukan sendiri permasalahan secara sistematis, kritis, logis, analitis, sehingga peserta didik dapat menemukan sendiri jawaban dari permasalahan yang ditemukan dengan rasa puas dan percaya diri dan mengakibatkan peningkatan hasil belajar siswa pada kelas eksperimen.Dari hasil data tersebut dapat dikatakan lebih banyak siswa dari kelas kontrol yang nilainya masih rendah dibandingkan kelas eksperimen. Menurut hasil analisis peneliti selama proses pembelajaran dari 5 siswa yang memperoleh nilai rendah diantaranya 2 orang siswa sering tidak turun sekolah dan 3 orang siswa lainnya kurang memperhatikan penjelasan materi selama pembelajaran berlangsung. Nilai tertinggi pretest awal hasil belajar peserta didik dikelas eksperimen diperoleh 55 dan nilai terendah 30, sedangkan nilai tertinggi hasil belajar peserta didik di kelas kontrol diperoleh 50 dan nilai terendah 30. Posttest akhir hasil belajar peserta didik di kelas eksperimen diperoleh nilai tertinggi 95 dan nilai terendah 50 , sedangkan untuk kelas kontrol diperoleh nilai tertinggi 85 dan nilai terendah 30 . Rata-rata nilai 
pretest awal pada kelas eksperimen adalah 43,28 dan kelas kontrol adalah 36,00. Rata-rata nilai akhir posttest hasil belajar peserta didik pada kelas eksperimen adalah 75,43 dan kelas kontrol adalah 61,14. Terlihat bahwa peningkatan kelas eksperimen lebih tinggi dari kelas kontrol baik nilai tertinggi, nilai terendah dan rata-rata yang diperoleh.

Hasil pretest maupun posttest kelas eksperimen dan kelas kontrol digunakan untuk menguji hipotesis yang telah diajukan penulis. Pengujian hipotesis dimaksudkan untuk mengetahui ada tidaknya perbedaan antara rata-rata nilai pretest dan posttest. Pengujian statistik dari data hasil pretest kelas eksperimen dan kelas kontrol terhadap hasil belajar siswa menunjukkan bahwa data yang diperoleh pada kelas eksperimen terdistribusi normal dan homogen sedangkan pada kelas kontrol data yang diperoleh tidak terdistribusi normal tetapi homogen. Hasil uji normalitas pada hasil pretest kelas eksperimen dengan uji Sahpiro Wilk sebesar 0,006 sedangkan pada kelas kontrol sebesar 0,000 . Maka pada kelas kontrol data diuji kembali dengan uji mann Whitnet Non Parametric karena hasil yang diperoleh tidak normal sehingga menggunakan uji Mann Whitney Non Parametric untuk mengetahui perbedaan hasil belajar dari kelas eksperimen dan kelas kontrol setelah diuji data menunjukkan hasil 0,000 sehingga dapat disimpulkan terdapat perbedaan hasil belajar dari pretest yang dilaksanakan karena data kurang dari 0,05 sehingga $\mathrm{H}_{\circ}$ ditolak dan $\mathrm{H}_{1}$ diterima dan hasil posttest dari kelas eksperimen dan kelas kontrol terdistribusi normal dan homogen dengan menggunakan terlihat bahwa kemampuan akhir hasil belajar berbeda dengan kemampuan awalnya. Pada kelas eksperimen maupun pada kelas kontrol mengalami peningkatan uji Shapiro Wilk. Hasil uji normalitas pada kelas eksperimen diperoleh data sebesar 0,095 sedangkan hasi data yang diperoleh dari kelas kontrol sebesar 0,346 yang lebih besar dari taraf signifikansi 0,05 , sehingga kedua data terdistribusi normal. Hasil uji homogenitas menggunakan uji Levene memperoleh nilai pada kelas eksperimen dan kelas kontrol lebih besar dari taraf signifikansi 0,05 yaitu 0,993 sehingga data homogen.

Berdasarkan hasil analisis, data yang diperoleh telah memenuhi syarat untuk dilakukannya uji t. Uji hipotesis yang peneliti adalah uji t equal varians karena jumlah sampel pada kelas kontrol dan kelas eksperimen sama. Dari hasil perhitungan hipotesis menggunakan uji $t$ yaitu dengan menganalisis hasil post-test kelas eksperimen yang diberikan perlakuan berupa pembelajaran problem based learning dan kelas kontrol diberikan perlakuan berupa pembelajaran yang sama tetapi tidak menggunakan eksperimen. Hasil uji $\mathrm{t}$ yang dilakukan dimana hasil thitung sebesar 4,74 dengan nilai signifikansi sebesar 0,000 (2-tailed) dengan taraf signifikansi $<0,05$ sehingga kedua data memiliki perbedaan hasil belajar yang signifikan dari nilai post-test antara kelas eksperimen dan kelas kontrol.

Berdasarkan analisis data diatas, maka hipotesis $\mathrm{Ho}$ ditolak dan $\mathrm{H}_{1}$ diterima sehingga dapat disimpulkan bahwa terdapat perbedaan hasil belajar yang signifikan antara kelas eksperimen yang menggunakan pembelajaran problem based learning dengan kelas kontrol yang menggunakan pembelajaran problem based learning tetapi tidak menggunakan eksperimen.

Berdasarkan diterimanya hipotesis yang dibuat oleh peneliti, hal ini disebabkan karena pada penelitian ini menggunakan pembelajaran problem based learning, dimana pembelajaran ini mempunyai kelebihan-kelebihan diantaranya membantu siswa untuk mengembangkan kemampuan siswa dan memudahkan siswa konsep yang dipelajari khususnya pada materi fluida statis dan dinamis terhadap hasil belajar pada materi yang diajarkan oleh peneliti. Selain itu pembelajaran ini juga mendorong siswa untuk menemukan suatu konsep sendiri melalui masalah yang di berikan oleh peneliti dalam bentuk lembar kerja peserta didik (LKPD) yang berguna sebagai alat untuk membantu proses pembelajaran agar peserta didik lebih aktif dan mandiri untuk memahami dan memecahkan masalah dari percobaan yang diberikan. Selain itu LKPD juga memudahkan pendidik (guru) dalam mengajar.

Selain itu pembelajaran problem based learning juga dapat dilihat pada tabel 6 dan tabel 7 data hasil belajar siswa, pada data tersebut sebanyak 16 siswa yang memperoleh nilai dengan kriteria baik sekali di kelas eksperimen sedangkan 4 siswa yang memperoleh nilai dengan kriteria baik sekali di 
kelas kontrol. Dari banyaknya siswa yang memperoleh niali tertinggi dari kriteria tersebut dapat ditarik kesimpulan bahwa penggunaan pembelajaran problem based learning dengan eksperimen dapat memberikan perbedaan hasil belajar pada kelas eksperimen dan kelas kontrol.

\section{PENUTUP}

Berdasarkan hasil penelitian dan analisis data yang telah dilakukan di SMA Negeri 2 Sendawar kelas eksperimen dan kelas kontrol dengan pembelajaran problem based learning untuk mengetahui perbedaan hasil belajar siswa pada kelas yang menggunakan eksperimen dan yang tanpa eksperimen di SMA Negeri 2 Sendawar, maka dapat disimpulkan bahwa: hasil belajar pada kelas yang menggunakan eksperimen lebih baik dibandingkan dengan kelas yang tidak menggunakan eksperimen sehingga terdapat perbedaan hasil belajar yang signifikan antara pembelajaran problem based learning pada kelas yang menggunakan eksperimen dan yang tanpa eksperimen.

Saran yang dapat diberikan berdasarkan penelitian yang telah dilakukan yaitu hasil belajar siswa dapat ditingkatkan dengan eksperimen pada pembelajaran problem based learning bila pembelajaran ini diterapkan secara terus menerus maka dapat meningkatkan hasil belajar siswa. Penelitian ini dapat dikembangkan dengan konsep fisika yang berbeda.

\section{DAFTAR PUSTAKA}

Djamarah. (2010). Strategi Belajar Mengajar. Jakarta: Rineke Cipta.

Jihad, A. \& Abdul, H. (2008). Evaluasi Pembelajaran. Yogyakarta: Multi Pressindo.

Nara, H. (2010). Teori Belajar dan Pembelajaran. Bogor: Ghalia Indonesia.

Purwanto. (2014). Evaluasi Hasil Belajar. Yogyakarta: Pustaka Belajar.

Rusman. (2010). Model-model Pembelajaran MengembangkanProfesionalisme Guru, Edisi Kedua. Jakarta : PT. Raja Grafindo Persada.

Sagala, S. (2012). Konsep dan Makna Pembelajaran. Bandung: Alfabeta
Siregar, E. \& Nara, H. (2010). Teori Belajar dan Pembelajaran. Bogor : Ghalia Indonesia.

Sugiyono. (2010). Metode Penelitian Pendidikan Pendekatan Kuantitatif, Kualitatif, dan $R \& D$. Bandung: Alfabeta

Suyanto, \& Jihad, A. (2013). Menjadi Guru Profesional: Strategi Meningkatkan Kualifikasi dan Kualitas Guru di Era Global. Jakarta : Erlangga. 